\title{
A new paedomorphic protasterid brittle star (Echinodermata, Ophiuroidea) from the Early Devonian of Luxembourg and Germany
}

\author{
Peter Müller ${ }^{1} \cdot$ Gerhard Hahn $^{2} \cdot$ Christian Franke $^{3} \cdot$ Ben Thuy $^{4}$ (D)
}

Received: 28 August 2018 / Accepted: 21 October 2018/Published online: 8 November 2018

(C) Akademie der Naturwissenschaften Schweiz (SCNAT) 2018

\begin{abstract}
A new genus of ophiuroid, Luxaster $\mathrm{n}$. gen., is described based on articulated skeletal remains preserved as external molds. The new genus belongs to the Paleozoic stem-group family Protasteridae. It includes two species, Luxaster martini $\mathrm{n}$. $\mathrm{sp}$. from the Lower Devonian of Luxemburg, and Luxaster schweitzeri from the Lower Devonian of W-Germany. Within the Protasteridae, Luxaster stands out in showing a combination of characters best interpreted as strongly paedomorphic within the morphological spectrum of the family. This suggests that paedomorphosis played a role in ophiuroid evolution not only in the living clades but also in the extinct stem groups.
\end{abstract}

Keywords Echinodermata $\cdot$ Ophiuroidea $\cdot$ Protasteridae $\cdot$ Luxaster $\cdot$ Lower Devonian · Luxembourg · Germany

\section{Introduction}

The family Protasteridae is one of the most widespread and long-lived groups of Paleozoic stem-group ophiuroids, with a fossil record ranging from the Ordovician to the Permian (Spencer and Wright 1966; Shackleton 2005; Hunter and McNamara 2018). Protasterid fossils have been found in all parts of the world, with the most notable Lower Devonian protasterid occurrences described from the Bundenbach fauna of the Hunsrück Slate (Glass and Blake 2004; Glass 2006) and the Malvinokaffric fauna of South Africa and the Falkland Islands (Jell and Theron 1999; Hunter et al. 2016).

One of the first more thorough analyses of the Protasteridae was proposed by Hammann and Schmincke (1986)

Editorial Handling: D. Marty.

Ben Thuy

bthuy@mnhn.lu

Peter Müller

mueller-lgh@t-online.de

1 Am Grauen Stein 4, 56244 Freilingen, Germany

2 Berliner Straße 31, 35282 Rauschenberg, Germany

3 Frankenstr. 28, 54675 Wallendorf, Germany

4 Department of Palaeontology, Natural History Museum Luxembourg, 25, rue Münster, 2160 Luxembourg City, Luxembourg who recognized three groups of genera based on the shape and length of the ambulacrals: their first group was characterized by short, triangular ambulacrals with well-developed muscle attachments and included the genera Drepanaster Whidborne, 1898, Protasterina Ulrich, 1878, Palaeophiomyxa Stürtz, 1899, Mastigophiura Lehmann, 1957 and Strataster Kesling \& La Vasseur, 1971; the second group was characterized by short, quadrate ambulacrals with a weakly developed muscle attachment and included Protaster Forbes, 1849, Bohemura Jaekel, 1903, Taeniaster Billings, 1858 und Eugasterella Schuchert, 1914; and finally the third group including Palaeophiura Stürtz, 1890 [considered by Glass (2006) as junior synonym of Bundenbachia Stürtz, 1886] and Chattaster Hahn \& Brauckmann, 1981 [as revised by Haude (1982)] with long (up to three times longer than wide), rectangular ambulacrals with only weakly discernible muscle attachments, if at all.

The next revision of the family was carried out by Glass and Blake (2004) who emphasized the characteristic boot shape of the ambulacrals and the sickle shape of the adambulacrals in ventral view as highly diagnostic. Shortly after, Shackleton (2005) proposed a thorough re-appraisal of the early Paleozoic asterozoans including the Protasteridae for which she emphasized the presence of paddleshaped ambulacral groove spines as a diagnostic character.

Hunter et al. (2016) adopted the diagnosis by Shackleton (2005) with some modifications and introduced the new 
subfamily Protasterinae characterized by alternating (in contrast to opposing) ambulacrals, the well-developed perradial suture, boot-shaped ambulacrals and large mouth angle plates, to accommodate the genera Darwinaster Hunter et al., 2016, Protaster, Drepanaster, Bundenbachia, Taeniaster, Palaeophiomyxa, Protasterina, Mastigophiura and Bohemura. The genera Eugasterella, Aulactis Spencer, 1930, Inyoaster Phleger, 1936, Chattaster, Strataster Kesling \& Le Vasseur, 1971, Astutuaster Boczarowski, 2001 and Weigeltura Boczarowski, 2001, in contrast, remain of unknown affinity, being currently recognized as protasterid but not explicitly assigned to the subfamily Protasterinae nor to any other subfamily.

Thus, over the past years, a cautious consensus has emerged as to how at least part of the protasterid morphological spectrum should be interpreted taxonomically. Nevertheless, many forms remain poorly known, and new genus-level taxa are still being discovered (e.g., Hunter et al. 2016; Hunter and McNamara 2018), progressively completing the picture of protasterid disparity.

Here, we describe new finds of ophiuroids from the early Devonian of Luxembourg and Germany that we identify as previously unknown protasterids. They stand out in showing a combination of characters best interpreted as paedomorphic within the protasterid morphological spectrum.

\section{Materials and methods}

All of the specimens described herein are preserved as external molds. All descriptions herein are based on silicone casts of these molds. Photographs were taken after coating the casts with magnesium oxide. Descriptions provided herein refer to the silicone casts of the external molds. The original specimens and casts of Luxaster martini gen. et sp. nov. are housed at the Natural History Museum Luxembourg (acronym: MnhnL EIB). The original specimen of Luxaster schweitzeri gen. et sp. nov. is lost. The cast of the original specimen is housed in the Landessammlung für Naturkunde Rheinland-Pfalz (Mainz, Germany) (acronym: PWL). Terminology follows Glass and Blake (2004) and Hunter and McNamara (2018).

\section{Geological context}

Merkholtz (Luxaster martini): the type locality of Luxaster martini is the northwestern quarry of the Carrière Merkholtz, a series of disused slate quarries at TC 6 Kautenbach in North Luxembourg (Fig. 1) [locality 30 of Franke (2006)]. The Klerf Beds that are exposed in this quarry form the topmost deposits of the lower Emsian in Luxembourg and the neighbouring Eifel in Germany. It mostly consists of poorly sorted sand- and siltstones, except for the more fine-grained fully marine deposits. The sediments of the Klerf Beds can be assigned to three major depositional settings: deltaic interdistributary areas, tidal flat deposits and shallow subtidal deposits under fully marine conditions.

The beds that yielded the ophiuroids described herein consist of fine-grained mudstones and siltstones with an uneven cleavage and yielding sparse, mostly deformed and altered fossils. Franke (2006) documented a moderately diverse marine fauna characterized by the relatively common homalonotid trilobite Burmeisterella vixarmata Wenndorf, 1990. Asterozoan resting traces (Asteriacites isp.) found on displaced boulders in the quarry most probably originate from these same beds. Recent fieldwork furthermore confirmed the presence of phyllocarid arthropods (leg M. Alberti, det M. Poschmann).

Trilobites in the beds in question are often preserved in the so-called Salter's configuration with the exuvia preserved undisturbed. This indicates burial in a relatively quiet depositional setting below wave base within the marine prodelta (Franke 2006; Alberti and Müller 2008; Müller and Alberti 2010).

Hirtscheid (Luxaster schweitzeri): the type locality of Luxaster schweitzeri is located some $150 \mathrm{~m}$ west of Hirtscheid (Fig. 1), a district of Alpenrod municipality in the Westerwald area (sheet Bad Marienberg, northern Rhineland-Palatinate, Germany). The outcrop "Am Mühlenhahn" is a 200-m slope that has been accessible since the mid-1970s. The exposed alternation corresponds to the typical Rhenish facies. It includes several fossiliferous beds (Müller 1997) with variable lithology and fossil content, ranging from shell beds devoid of articulated skeletons to beds with relatively common intact echinoderms (Schweitzer 1977; Müller 1997; Müller and Alberti 2010). Müller $(1995,1997)$ mentions more than 100 taxa from these beds, including some 20 echinoderms belonging to the Crinoidea, Asteroidea and Ophiuroidea (the heredescribed specimens and another undescribed six-armed ophiuroid).

The trilobite fauna is dominated by the Homalonotinae typical for the middle early Emsian: Digonus ornatus ornatus (Koch, 1883), Burmeisterella armata (Burmeister, 1843), Arduennella maillieuxi (Asselberghs, 1923), Dipleura laevicauda (Quenstedt, 1852) and Spiniscabrella sp.. Stratigraphically relevant brachiopods are Euryspirifer cf. dunensis (Kayser, 1899) and Brachyspirifer crassicosta (Scupin, 1900). Thus, the exposed succession can be dated to the middle early Emsian Singhofen substage or Bendorf substage sensu Mittmeyer (2008) or lower Vallendar substage and is stratigraphically slightly older than the Klerf Beds (upper Vallendar substage) exposed in Merkholtz. 


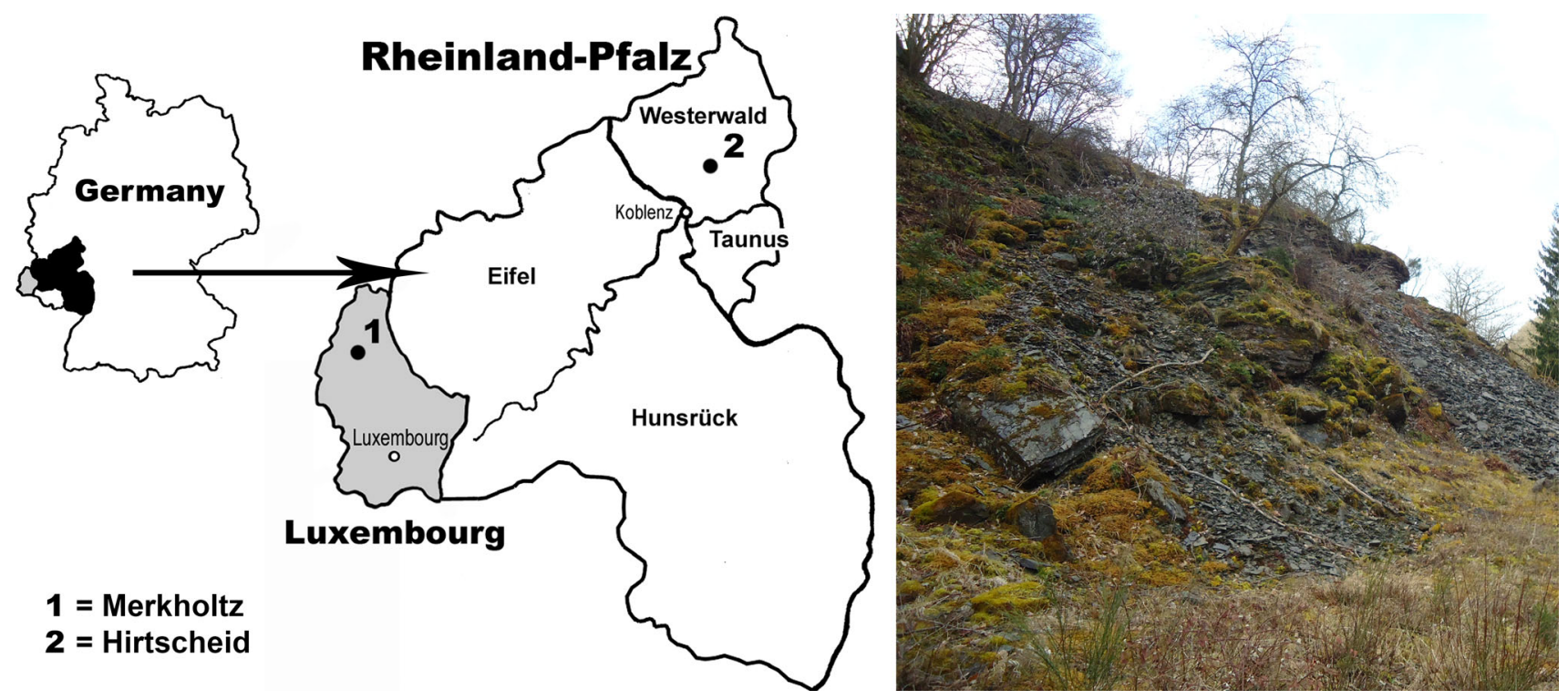

Fig. 1 Maps showing the position of the Merkholtz and Hirtscheid localities, and photograph of the Merkholtz locality taken in spring 2018

Palaeogeographically, both the Merkholtz and the Hirtscheid localities are reconstructed as near-coastal settings of the Rheic Ocean on the southern continental shelf of Laurussia.

\section{Systematic palaeontology}

Class Ophiuroidea Gray, 1840

Family Protasteridae Miller, 1889

Subfamily Protasterinae Hunter et al., 2016

Genus Luxaster gen. nov.

\section{Type species Luxaster martini n. sp.}

Diagnosis Protasterid ophiuroid with disc devoid of spines and discernible disc scales except for a row of small marginal plates; madreporite not discernible; ambulacrals between two and three times longer than wide; lateral arm plates with very small, inconspicuous lateral arm spine articulations, and a single longitudinal ridge lining the adradio-distal edge of the lateral arm plates instead of ambulacral groove spine articulations.

Derivatio nominis Combination of Lux(embourg) and $\alpha \sigma \tau \varepsilon \rho($ greek $)=$ star, in reference to the origin of the type species.

\section{Other species included Luxaster schweitzeri}

Occurrence Early Devonian (Emsian) of Luxembourg and W-Germany

Luxaster martini $\mathrm{n} . \mathrm{sp}$.

Fig. 2
Derivatio nominis Species named in honour of Martin Müller (Langenhahn), who discovered the holotype.

Holotype MnhnL EIB366 (Fig. 2a-d), external mold of a complete skeleton exposing both the ventral and the dorsal sides.

Paratype MnhnL EIB367 (Fig. 2e-h), external mold of an isolated arm exposing both the ventral and the dorsal sides.

Type locality northwestern quarry of the Carrière Merkholtz, Luxembourg.

Type stratum Early Devonian, Emsian, Klerf-Formation.

Diagnosis Species of Luxaster with moderately long arms, very narrow. Ambulacrals three times longer than wide. Lateral arm plates widely extending ventrally, strongly bent, partly covering the ambulacra; five marginal plates per interradius.

Description of holotype The holotype is an external mold of an articulated skeleton, total diameter (disc plus arms) $\sim 28 \mathrm{~mm}$, diameter of the central disc $\sim 8 \mathrm{~mm}$, with a complete dorsal side and a ventral side with two arms lacking their tips. The arm pointing upwards in Fig. 2a, b is referred to as "arm 1", numbering of the other arms follows clockwise (dorsal side). The disc (Fig. 2c) is relatively large and accounts for approximately one fourth of the total diameter. It underwent a slight postmortem distortion. Disc plates or scales are visible neither on the dorsal side nor on the ventral side. No madreporite discernible. The outer edge of the disc is formed by a concave row of marginal plates, resulting in a weakly lobed disc outline. There are five such marginal plates in every interradius. They are about twice as wide as long, convex 

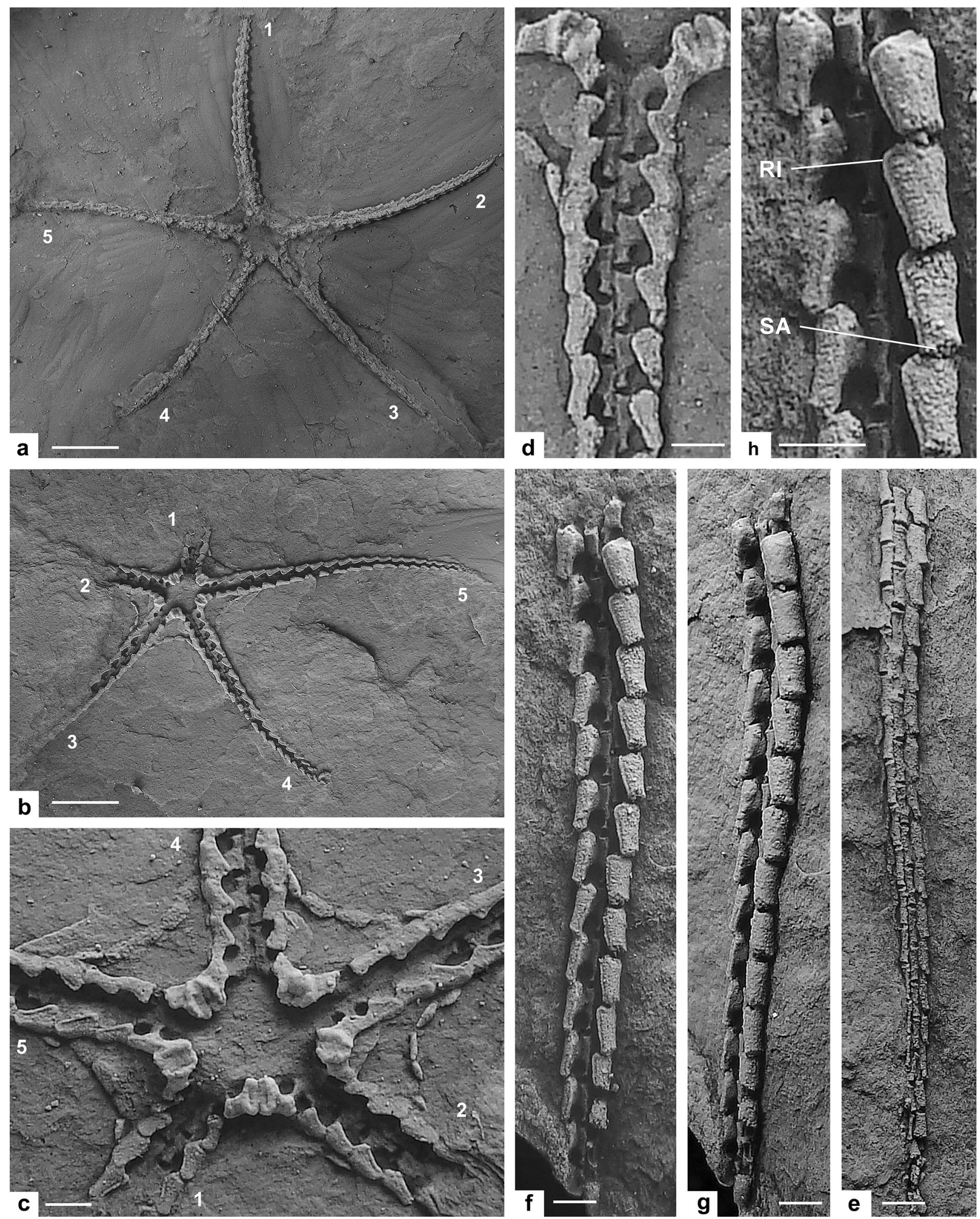
4Fig. 2 Luxaster martini gen. et sp. nov., from the Lower Devonian, Emsian, Klerf-Formation of the northwestern quarry of the Carrière Merkholtz, Luxembourg. a-d Cast of complete specimen, MnhnL EIB366 (holotype). a Dorsal side with arms numbered; b ventral side with arms numbered; c detail of disc in ventral view with arms numbered; d detail of proximal arm segments (arm 4) and jaws in ventral view. e-h Cast of arm fragment, MnhnL EIB367 (paratype). e Dorsal side; $\mathbf{f}$ ventral side in ventral view; $\mathbf{g}$ ventral side in ventrolateral view; $\mathbf{h}$ detail of proximal arm segments in ventral view. $R I$ ridge, $S A$ spine articulations. Scale bars equal $5 \mathrm{~mm}$ in $\mathbf{a}$, b, and $1 \mathrm{~mm}$ in $\mathbf{c}-\mathbf{h}$

and probably finely tuberculous. Larger cusps or pores for the attachment of spines are missing. The marginal plates are well preserved between arms 5 and 1, 2 and 3, and 3 and 4 , and are indistinct between arms 1 and 2, and 4 and 5 (Fig. 2c).

The mouth region (Fig. 2c, d) is large but has very small, short mouth angle plates that protrude into the mouth only for one fourth of its diameter. Neighbouring mouth angle plate pairs do not abut and have a bean-shaped outline. Each mouth angle plate has a convex blunt bulge in the outer half and a distinct elongated dent in the inner half to accommodate the radial internal muscle (sensu Hammann and Schmincke 1986: 69). At the aboral edge, both bulges meet. The mouth angle plates of a pair abut over almost their entire length, and gape slightly apart only at their proximal end. The median longitudinal furrow between the mouth angle plates is well defined. No dental plates or teeth are discernible at the proximal tip of the mouth angle plates. No transverse channel for the water vascular system is discernible. The mouth angle plates are best preserved between the arms 5 and 1, to which the three proximal arm segments with their podial basins articulate within the central disc. No scales or other skeletal elements are discernible in the lumen of the oral cavity.

The arms (Fig. 2a-d) are narrow and moderately long. They are comprised of approximately 25 long and narrow segments. The distalmost discernible arm segments are still open and not completely covered by the lateral arm plates. The median channel for the radial canal is clearly visible until distal arm segments. The podial basins are large and encompassed half by the ambulacral and half by the lateral arm plate.

The arm segments (Fig. 2d) are comprised of two ambulacrals and lateral arm plates. The ambulacrals are rectangular in shape and three times longer than wide. Opposing ambulacrals are offset along the arm midline by slightly more than one third of their length in proximal to median arm portions. The dorsal side is slightly concave radially; the proximal and distal edges are raised like beads and thickened. Their surface is composed of coarsely meshed stereom; other microstructures such as muscle fossae are not visible. The radial boundary between the two opposing rows of ambulacrals halves is clearly defined. The ventral side of the ambulacrals shows the typical "boot"-form of the Protasteridae. The "toe" $\left(W_{\mathrm{T}}\right)$ is narrow, albeit wider than the central leg $\left(W_{\mathrm{CL}}\right)$, and pointed abradially. The "foot" is longer $\left(L_{\mathrm{F}}\right)$ than wide $\left(W_{\mathrm{F}}\right)$, and slightly longer than the remaining part of the leg $\left(L_{\mathrm{L}}-L_{\mathrm{F}}\right)$. The central leg $\left(W_{\mathrm{CL}}\right)$ and distal fitting $\left(W_{\mathrm{CF}}\right)$ are equally narrow. The lace area is rounded. In some ambulacrals, the "foot" has one or two small spurs at the distal edge. It forms a small tip at the distal edge of the podial basin. Next to the tip, the "foot" is concave adradially and abradially. In some ambulacrals, the surface of the "foot" is covered with a faint tuberculation. The podial basin is large and half enclosed by the "foot".

The lateral arm plates are rectangular, weakly constricted and completely enclosing the ambulacrals laterally. The outer surface of the lateral arm plates has a fine tuberculation. In dorsal view, the lateral arm plates are narrow, long, rod-shaped, about half as wide as the associated ambulacral in proximal to median arm portions. The lateral arm plate is in contact with the ambulacral over its entire length. The outline of the lateral arm plates in ventral view is rectangular and tapers slightly distalwards; the adradial edge of the lateral arm plate is slightly sinuous and paralleled by a well-defined ridge extending around the adradio-proximal angle. Although no distinct spine articulations are discernible on the ridge, it cannot be ruled out that it originally carried ambulacral groove spines. The distal edge of the lateral arm plates shows very small, poorly defined spine articulations integrated into the outer surface stereom and consisting of simple openings encompassed by a circular or horseshoe-shaped ridge. No arm spines are discernible.

Paratype supplements and variation The paratype (Fig. 2e-h) is an external mold of an isolated arm preserving both dorsal and ventral sides. It has a length of $18 \mathrm{~mm}$ and is comprised of 15 vertebrae. Morphologically, it is well in agreement with the holotype. The total original diameter (disc plus arms) of the individual can be reconstructed to about $50 \mathrm{~mm}$.

Luxaster schweitzeri n. sp.

Fig. 3

1977 Schlangensterne.-Schweitzer, Fossilien im Westerwald: 40-41, Fig. 33.

1983 Schlangensterne.-Roth, Siegerland, Westerwald, Lahn u.Taunus: Fig. S. 26.

1995 Schlangenstern.-Müller, Fossile Stachelhäuter im Westerwald: 98, Fig. 5.

1997 Ophiuridae indet.-Müller, Fossillagerstätten im Westerwald: 15, 18. 

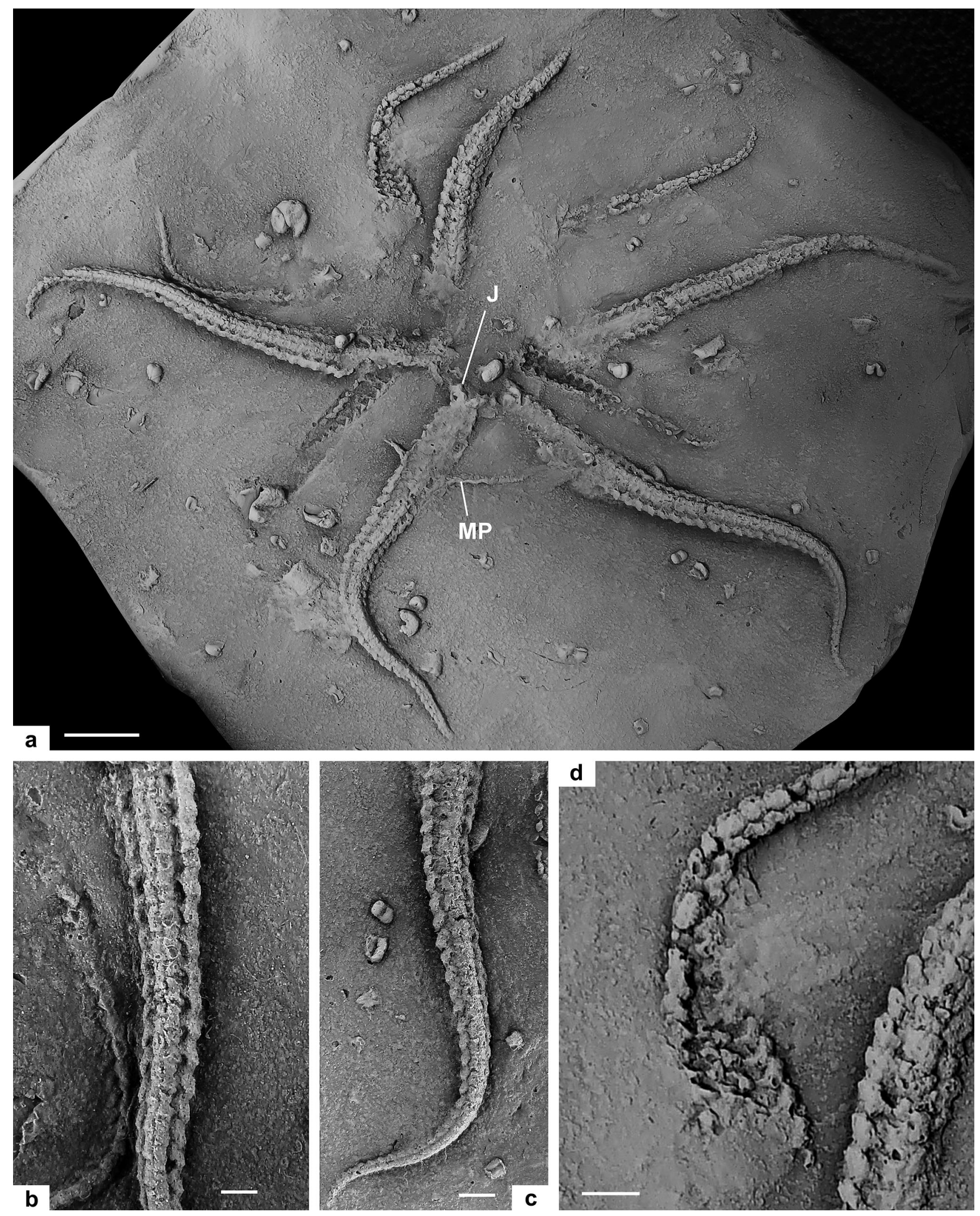
4Fig. 3 Luxaster schweitzeri gen. et sp. nov., from the lower Emsian, Lower Devonian, Singhofen-Formation of the outcrop "Am Mühlenhahn", 150 m west of Hirtscheid, a district of Alpenrod municipality in the Westerwald area, Germany. a Cast of holotype (PWL 2018/5461-1-LS) and paratype (PWL 2018/5461-2-LS) specimens; b holotype specimen, showing detail of proximal to median arm segments in dorsal view; c holotype specimen, showing detail of median to distal arm segments in dorsal view; d paratype specimen, showing detail of proximal arm segments in ventral view. $J$ jaws composed of mouth angle plates; $M P$ marginal plates. Scale bars equal $5 \mathrm{~mm}$ in $\mathbf{a}$, and $1 \mathrm{~mm}$ in $\mathbf{b}-\mathbf{d}$

Derivatio nominis Species named after late Friedel Schweitzer (Westerburg), who discovered the holotype.

Holotype specimen PWL 2018/5461-1-LS exposing the dorsal side, i.e., the upper one of the two overlapping individuals (Fig. 3) -total diameter (disc plus arms) of $\sim 66 \mathrm{~mm}$.

Paratype Specimen PWL 2018/5461-2-LS exposing the ventral side, i.e., the slightly smaller, lower one of the two overlapping individuals (Fig. 3) —total diameter (disc plus arms) of $\sim 43 \mathrm{~mm}$.

Locus typicus Outcrop “Am Mühlenhahn”, 150 m west of Hirtscheid, a district of Alpenrod municipality in the Westerwald area (sheet Bad Marienberg, northern Rhineland-Palatinate, Germany).

Stratum typicum Lower Devonian, lower Emsian, Singhofen-Formation.

Diagnosis Species of Luxaster with relatively long and slender arms and with ambulacrals two times longer than wide; up to ten marginal plates per interradius.

Description of holotype Articulated individual preserving all five arms from the base to the tip but with only part of the central disc discernible. The disc (Fig. 3a) only preserves remains of the marginal plates on two sides of one arm base. They are narrow and their number can be reconstructed to about 10 per interradius. They run, as far as recognizable, in an almost straight line between the arms. Disc plates or scales are not visible and were probably not present. Between the jaws and the marginal plates there are 5-6 arm segments.

The mouth region (Fig. 3a) shows small V-shaped jaws protruding to the mouth region at the proximal tip of two arms. The jaws are composed of small, short mouth angle plates. No details of the mouth angle plate microstructure are discernible.

The ambulacrals (Fig. 3b, c) are about twice as long as wide. Both ambulacral halves are offset from each other. Their surface is approximately even and roughened; muscle fossae are only visible in a few places. The central longitudinal channel for the radial neural canal is not very clear. The lateral arm plates encompass the lateral edges of the ambulacrals at an acute angle with respect to the arm midline. The lateral arm plates show a similarly rough surface as the ambulacrals.

The arms are moderately narrow, relatively long and composed of approximately 40 segments. The distal parts are better preserved than the proximal ones. The arms taper regularly.

Paratype supplements the paratype (Fig. 3) is an articulated individual exposing the ventral side and showing only parts of the five arms because of the overlapping with the holotype specimen. The ambulacrals (Fig. 3d) are offset to about half of their length. The podial basins are large and are encompassed by the ambulacral and the lateral arm plate. The morphological details of the ambulacrals can no longer be determined. The lateral arm plates are only slightly more prominent ventralwards than the ambulacrals and do not encompass them ventrally. The boot shape is weakly pronounced, possibly due to poor preservation. There are no arm spines discernible and the arm spine articulations are very small and inconspicuous.

\section{Discussion}

The ophiuroid specimens described above are unambiguously identifiable as members of the Protasteridae on account of their boot-shaped ambulacrals. Within this family, however, they stand out in having discs devoid of spines and discernible plates and scales except for small marginal scales, and in having small, inconspicuous lateral spine articulations suggesting very small, short arm spines. Most other protasterids have large, conspicuous lateral arm spines (e.g. Glass 2006; Hunter and McNamara 2018). Other notable characters of the specimens described herein are the small, slender, bean-shaped mouth angle plates, and the long, rectangular ambulacrals that are between two (Hirtscheid specimens, i.e., Luxaster schweitzeri) and three (Merkholtz specimens, i.e., Luxaster martini) times longer than wide. Within the protasterids, similarly elongate ambulacrals are only known in Bundenbachia and Chattaster. The disc integument in the specimens described herein is devoid of spines and was covered only by very thin scales, if at all, which excludes assignment to Bundenbachia and to almost all other protasterids (e.g., Glass 2006). Similarities are greatest with Chattaster as revised by Haude (1982), especially with respect to the disc covering and the elongated ambulacrals. The specimens described herein, however, differ in having a ring of small, readily discernible marginal scales encompassing the disc, and in lacking the long arm spines attached to conspicuous 
spine articulations typically found in Chattaster. In the light of these differences, it seems warranted to introduce the new genus Luxaster to accommodate the new finds from Luxembourg and Germany.

Although the two sets of specimens described herein all share the same fundamental set of characters, setting them apart from other protasterids and favouring assignment to the same genus, they differ in some aspects of the arm skeleton: the proportions of the ambulacrals (two versus three times longer than wide), the number of segments per arm ( 25 versus 40$)$, and the extent to which the lateral arm plates ventrally encompass the ambulacrals. The sole articulated skeleton from the Merkholtz locality is much smaller than the two articulated individuals from Hirtscheid, thus raising the possibility that the differences might be related to size and/or ontogeny. The arm fragment from Merkholtz, however, shows the same set of characters as the co-occurring articulated skeleton but belonged to a much larger individual, of comparable size as the Hirtscheid individuals. This suggests that the Merkholtz specimens, described herein as Luxaster martini sp. nov., indeed represent a different species rather than an ontogenetically earlier stage of the Hirtscheid specimens described as Luxaster schweitzeri sp. nov.

The characters that set apart the new genus Luxaster from its protasterid relatives share a striking feature: they all point to a reduced or ontogenetically immature state of skeletal development. Little is known about the ontogenetic development of Paleozoic stem-group ophiuroids but an unnamed juvenile protasterid described by Haude and Thomas (1983) indicates that elongated ambulacrals as well as elongated lateral arm plates covering large parts of the ambulacral groove and lacking readily discernible arm spines are, indeed, typically juvenile characters. In modern ophiuroids, the absence of readily discernible disc scales, strongly elongated arm segments with small, inconspicuous spine articulations, and coarsely meshed stereom are considered as paedomorphic traits, i.e., juvenile traits that are retained into adulthood (Stöhr and Martynov 2016). We, therefore, conclude that the Luxaster species can be considered as paedomorphic. The possibility that the Luxaster specimens simply represent juvenile individuals is rejected because of their size and the absence of any trace of larger protasterids at both localities. Our observations suggest that the developmental trend hinted at by Haude (1982) with respect to Chattaster, in fact, also reflects paedomorphosis.

The discovery of Luxaster widens the morphological spectrum of the Protasteridae, adding a clearly paedomorphic representative. It also suggests that paedomorphosis already played a role in ophiuroid evolution as early as in the Devonian.
Acknowledgements We thank Martin Müller (Langenhahn) for donating the holotype of Luxaster martini, and Dipl. Geol. Mirco Alberti (Bornheim), Dr. Ulrich Jansen (Senckenberg research institute, Frankfurt/Main), Markus Poschmann (Koblenz), Dr. Jochen Schweitzer (Johannesburg), Dr. Klaus-Werner Wenndorf (Braubach) for helpful information on localities and the associated fauna. The comments by four anonymous reviewers improved an earlier version of this article.

\section{References}

Alberti, M., \& Müller, P. (2008). Burmeisterella vixarmata WENNDORF 1990: Eine Rekonstruktion. Fossilien, 4(2008), 235-238.

Asselberghs, E. (1923). Homalonotus maillieuxi, espèce nouvelle du Hunsrückien de la Belgique. Bulletin de la Société Belge de Géologie, 33, 29-32.

Billings, E. (1858). On the Asteriadae of the Lower Silurian rocks of Canada. Figures and descriptions of Canadian Organic Remains. Geological Survey of Canada, Decade, 3, 75-85.

Boczarowski, A. (2001). Isolates sclerites of Devonian non-pelmatozoan echinoderms. Palaeontologia Polonica, 59, 1-219.

Burmeister, H. (1843). Die Organisation der Trilobiten aus ihren lebenden Verwandten entwickelt; nebst einer systematischen Übersicht aller seither beschriebenen Arten. I-XII, 1-147, Taf. 1-6. Berlin: Verlag G. Reimer.

Forbes, E. (1849). On the Asteriadae found fossil in British strata. Memoirs of the Geological Survey of Great Britain and Museum of Practical Geology, 2, 457-482.

Franke, C. (2006). Die Klerf-Schichten (Unter-Devon) im Großherzogtum Luxemburg, in der Westeifel (Deutschland) und im Gebiet von Burg Reuland (Belgien): fazielle und biostratigraphische Deutung. In Franke (ed.): Beiträge zur Paläontologie des Unterdevons Luxembourgs (1). Ferrantia, 46, 42-96.

Glass, A. (2006). The Brittle Star fauna of the Hunsruck Slate and a phylogeny of the Paleozoic Ophiuroidea. Dissertation. UrbanaChampaign: Univ. Illinois.

Glass, A., \& Blake, D. B. (2004). Preservation of tube feet in an ophiuroid (Echinodermata) from the Lower Devonian Hunsrück Slate of Germany and a redescription of Bundenbachia beneckei and Palaeophiomyxa grandis. Paläontologische Zeitschrift, 78, $73-95$.

Gray, J. E. (1840). Synopsis of the contents of the British Museum (42nd ed., p. 370). London: Woodfall and Son.

Hahn, G., \& Brauckmann, C. (1981). Ein neuer Ophiuren-Fund aus dem Kulm von Herborn (Asterozoa, Unter-Karbon IIIa, Hessen). Geologisches Jahrbuch Hessen, 109, 5-18.

Hammann, W., \& Schmincke, S. (1986). Depositional environment and systematics of a new ophiuroid Taeniaster ibericus n. sp. from the Middle Ordovician of Spain. Neues Jahrbuch für Geologie und Paläontologie Abhandlungen, 173, 47-74.

Hunter, A. W., \& McNamara, K. J. (2018). Prolonged co-existence of 'archaic' and 'modern' Palaeozoic ophiuroids-Evidence from the early Permian, Southern Carnarvon Basin, Western Australia. Journal of Systematic Palaeontology, 16, 891-907.

Hunter, A. W., Rushton, W. A., \& Stone, P. (2016). Comments on the ophiuroid family Protasteridae and description of a new genus from the Lower Devonian of the Fox Bay Formation, Falkland Islands. Alcheringa, 40(4), 429-442.

Jaekel, O. (1903). Über Asteriden und Ophiuriden aus dem Silur Böhmens. Zeitschrift der Deutschen Geologischen Gesellschaft, $55,106-113$.

Jell, P. A., \& Theron, J. N. (1999). Early Devonian echinoderms from South Africa. Memoirs of the Queensland Museum, 43, 115-199. 
Kesling, R. V., \& Le Vasseur, D. (1971). Strataster ohioensis, a new Early Mississippian brittle-star, and the paleoecology of its community. Contributions from the Museum of Paleontology. The University of Michigan, 23(20), 305-341.

Koch, C. (1883). Monographie der Homalonotus-Arten des Rheinischen Unterdevons. Abhandlungen zur Geologischen Specialkarte von Preußen und den Thüringischen Staaten, 4, 1-85.

Lehmann, W. M. (1957). Die Asterozoen in den Dachschiefern des rheinischen Unterdevons. Abhandlungen des Hessischen Landesamtes für Bodenforschung, 21, 1-160.

Miller, S. A. (1889). North American geology and palaeontology for the use of amateurs, students, and scientists (p. 664). Cinncinati, Ohio: Western Methodist Book Concern.

Mittmeyer, H. G. (2008). Unterdevon der Mittelrheinischen und Eifeler Typ-Gebiete (Teile von Eifel, Westerwald, Hunsrück und Taunus). In Deutsche Stratigraphische Kommision (Ed.), Stratigraphie von Deutschland VIII. Devon. Schriftenreihe der Deutschen Gesellschaft für Geowissenschaften, 52, 139-203.

Müller, P. (1995). Fossile Stachelhäuter im Westerwald. Jahrbuch des Westerwald-Kreises, 1995, 95-98.

Müller, P. (1997). Fossillagerstätten im Westerwald. Westerburger Hefte, 25, 1-53.

Müller, P. \& Alberti, M. (2010). Burmeisterella vixarmata aus der Klerf-Formation in Nord-Luxembourg. In Franke (Ed.), Beiträge zur Paläontologie des Unterdevons Luxembourgs (2). Ferrantia, 58, 63-71.

Phleger, F. B. (1936). An Ordovician auluroid from California. Southern California Academy of Science, Bulletin, 35, 82-83.

Quenstedt, F. A. (1852). Handbuch der Petrefactenkunde (1st ed., p. 792). Tübingen: Laupp.

Schuchert, C. (1914). Stelleroidea palaeozoica. Fossilium Catalogus I. Animalia (p. 53). Berlin: W. Junk.

Schweitzer, F. (1977). Fossilien im Westerwald. Westerburger Hefte, $8,1-49$.
Scupin, H. (1900). Die Spiriferen Deutschlands. Palaeontologische Abhandlung, Neue Folge, 4, 207-344.

Shackleton, J. D. (2005). Skeletal homologies, phylogeny and classification of the earliest asterozoan echinoderms. Journal of Systematic Paleontology, 3, 29-114.

Spencer, W. K. (1930). A monograph of the British Palaeozoic Asterozoa. Part. 8. Monograph of the Palaeontographical Society. London, 82 (for 1928), 389-436.

Spencer, W. K., \& Wright, C. W. (1966). Asterozoans. In R. C. Moore (Ed.), Treatise on invertebrate paleontology, Part U, Echinodermata 3 (pp. U1-U107). Boulder, Colorado/Lawrence, Kansas: The Geological Society of America/University of Kansas Press.

Stöhr, S., \& Martynov, A. (2016). Paedomorphosis as an evolutionary driving force: insights from deep-sea brittle stars. PLoS One, 11(11), e0164562.

Stürtz, B. (1886). Beitrag zur Kenntnis palaeozoischer Seesterne. Palaeontographica, 32, 75-98.

Stürtz, B. (1890). Neuer Beitrag zur Kenntnis palaeozoischer Seesterne. Palaeontograpica, 36, 203-247.

Stürtz, B. (1899). Ein weiterer Beitrag zur Kenntnis palaeozoischer Asteroiden. Verhandlungen des Naturhistorischen Vereins der Preussischen Rheinlande, Westfalens und des RegierungsBezirks Osnabrück, 56, 176-240.

Ulrich, E. O. (1878). Descriptions of some new species of fossils, from the Cincinnati Group. Journal of the Cincinnati Society of Natural History, 1, 92-100.

Wenndorf, K. W. (1990). Homalonotinae (Trilobita) aus dem rheinischenn Unterdevon. Palaeontographica, 211, 1-184.

Whidborne, G. F. (1898). A monograph of the Devonian fauna of the South of England. 3. The fauna of the Marwood and Pilton beds of North Devon and Somerset (Part 3, 3). Palaeontographical Society Monograph, 52(247), 179-236. 